\title{
TINJAUAN KRITIS TERHADAP AJARAN FREDRICH SCHLEIERMACHER DALAM HUBUNGANNYA DOKTRIN DASAR KRISTEN
}

\author{
Titus \\ Sekolah Tinggi Teologi Injili Indonesia - Samarinda \\ E-mail: titusturotbene@gmail.com
}

\begin{abstract}
God created man with many uniqueness from all other types of creation, one of which is the ability to think and reason about something. The purpose of this uniqueness is for humans to become divine partners in protecting and caring for the earth and what is in it. But unfortunately that uniqueness is tainted by because man's own disobedience to God's prohibition in the Garden of Eden.

Even so, the human ability to think and reason is not lost. Humans are given the opportunity to work to work on this damaged earth even with pain. This ability to think continues to develop in great works and has become an icon of human civilized history. seen from historical buildings, but also through thoughts that can influence the challenges in people's lives, that is the fruit of the uniqueness of human thought that was created by God.

Human thought that has developed over a period of time has become a disaster, where God is no longer needed in the modern world, the rise of liberal theology brings out the power of intellectual thought and intuition. The purity of Christian teachings has become relative and dragged into a vortex of increasingly sharp criticism. Can the Bible dim the teaching deviations, straighten out the understanding that has been dragged into corrupted rationale.
\end{abstract}

Keywords: Critical, Liberal Theology, Bible

\begin{abstract}
Abstrak
Tuhan menciptakan manusia dengan banyak keunikan dari segala jenis ciptaan lainnya, salah satunya adalah kemampuan untuk berpikir dan menalarkan sesuatu.Tujuan dari keunikan itu adalah supaya manusia menjadi mitra Ilahi dalam menjaga dan memelihara bumi serta yang ada di dalamnya.Tetapi sayang keunikan itu tercemar oleh karena ketidaktaatan manusia itu sendiri terhadapan larangan Allah di Taman Eden.

Walaupun demikian kemampuan manusia untuk berpikir dan bernalar tidak hilang, manusia diberi kesempatan untuk berkarya mengusahakan bumi yang sudah rusak itu meskipun dengan bersusah payah.Kemampuan berpikir itu terus berkembang dalam sebuah karya-karya besar dan menjadi ikon sejarah beradaban manusia.Karya agung itu bukan hanya terlihat dari bangunan-bangunan bersejarah, tetapi juga melalui pemikiran-pemikiran yang dapat mempengaruhi tantanan dalam kehidupan masyarakat, itulah buah dari keunikan pemikiran manusia yang diciptakan Allah.

Pemikiran manusia yang semakin berkembang dalam kurun waktu tertentu menjadi petaka, dimana Allah menjadi tidak diperlukan lagi dnia modern, kebangkitan teologi liberal menyuguhkan kekuatan pemikiran intelektual dan intuisi. Kemurnian ajaran Kristen menjadi
\end{abstract}


Jurnal Teologi \& Pelayanan ( Kerusso )

E-ISSN: 2714-9587

P-ISSN: 2407-554X

menjadi relative dan terseret dalam pusaran kritik yang semakin tajam.Mampukah Alkitab meredupkan penyimpangan pengajaran, meluruskan pemahaman yang terseret dalam rasional yang tercemar.

Kata Kunci: Kritis, teologi liberal, Alkitab

\section{Introduction}

Allah menciptakan manusia dengan daya kreatif yang tinggi, agar dapat berkarya dibumi ini untuk menyatakan kemuliaan-Nya.Pemikiran yang cerdas dan imajinasi yang tinggi perlu diselaraskan dengan kehendak Allah agar tidak menyimpang dari tujuan mengapa manusia itu diciptakan.

Ada sebuah ungkapan yang menarik "setiap masa ada tokohnya dan setiap tokoh ada masanya" "Ungkapan ini menunjukan tentang sejarah pemikiran tokoh-tokoh filsafat yang mempengaruhi dunia, baik dunia pendidikan, sosial dan agama. Dalam kehidupan masyarakat modern, rasio dianggap sebagai pemegang otoritas tertinggi dalam mengatur seluruh kehidupan " moto manusia modern menjadi beranilah menggunakan pengertianmu sendiri, bebaslah untuk berpikir tanpa sangsi, tanpa pengarahan dari luar diri manusia, bangunlah dari ketiduran dogmatis" 2

Dari abad ke abad pemikiran manusia semakin berkembang dan banyak pemikiran-pemikiran muncul dengan berbagai teori yang mempengaruhi dunia. Memasuki Abad ke 19 adalah abad di mana manusia masuk dalam arena pemikiran yang penuh dengan tantangan karena perkembangan ilmu pengetahuan dan teknologi yang menyajikan kemudahan-kemudahan bagi manusia untuk mendapatkan informasi dan

\footnotetext{
${ }^{1}$ Amiruddin Wasugai, Diskusi kelas persentasi kelompok 5 "Filsafat Eksistensialisme" mata kuliah Coloqium Didacticum, Sabtu, 10 Oktober 2020.

${ }^{2}$ Immanuel Kant, "Beantwortung der Frage: Was ist Aufklarung": Berlinische Monatsshrift, December 1787 ( Gesammelte Schriften, Berlin, VIII) hal. 35 .
}

kebutuhan hidup. "keyakinan manusia modern pada kemampuan rasio untuk menggapai dunia materi dan ketidakmampuan rasio untuk menerangkan segala sesuatu yang ada diluarnya" 3 Pemikiran religius modern menempatkan rasio sebagai alat untuk mengerti tentang keberadaan Allah rumusan pemikiran dikemukakan Immanuel Kant “ ia menyangkal bukti-bukti dari eksistensi Allah, dan mempertahankan bahwa manusia hanya dapat mengetahui Allah melalui penalarannya." ${ }^{4} \quad$ Era ini disebut dengan masa pencerahan yang memandang rendah tradisi dan otoritas Alkitab tetapi menganggap kebebasan bernalar adalah ukuran untuk mengenal Allah.Masa pencerahan dan filsafat Immanuel Kant serta aliran romantisisme dan immanentesme mempengaruhi seorang teolog yang bernama Friedrich Daniel Ernst Schleiermacher.

Schleiermacher dikenal sebagai bapak teologi modern dan sangat berpengaruh pada abad ke-19, pemikiranpemikirannya yang luas tentang teologi juga berpengaruh pada para teolog abad ke-20. Banyak karya-karya besarnya yang menjadi warisan para teolog modern yang beraliran liberal. Karl Bart pernah mengatakan bahwa " Ia tidak hanya membentuk suatu aliran baru, tetapi suatu zaman baru. Ia bukan saja pendiri liberal, tetapi pendiri dari seluruh teologi modern."5

Pemikiran kaum liberal terhadap teks Alkitab dan teologi-teologi Kristen

\footnotetext{
${ }^{3}$ Colin Brown , Philosophy and the Christian Faith ( Chicago: IVP, 1969) 91.

${ }^{4}$ Paul Enns, The Moody Handbook Of

Theology,Pen, Rahmiati Tanudjaja. ( Malang:SAAT, 2012), 92.

${ }^{5}$ Ibid, hal 198
} 
lainnya memiliki perbedaan yang cukup tajam, pandangan kaum liberal berusaha memahami Alkitab dan mencari makna Alkitab masa kini sehingga melupakan makna teks atau konteks sejarah yang terjadi pada saat Alkitab itu ditulis. Penekanan pandangan kaum liberal lebih kepada alegoris bukan literal dan tekstual.

\section{Metode}

Penelitian ini akan membahas apa saja pandangan-pandangan Friedrich Daniel Ernst Scheiermacher dalam doktrin dasar iman Kristen? Kedua, apakah ada pengaruh ajaran Friedrich Daniel Ernst Schleiermacher terhadap doktrin dasar iman Kristen.

Tujuannya yaitu. Menguraikan pandangan-pandangan Friedrich Daniel Ernst Schleiermacher tentang doktrin dasar Kristen. Kedua, Memberikan argumentasiargumentasi terhadap pandangan Friedrich Daniel Ernst Schleiermacher mengenai doktrin dasar Kristen.

\section{Pandangan Friedrich Daniel Ernst Schleiermacher}

Setiap orang diberikan Tuhan kemampuan untuk memikirkan sesuatu, baik itu mengenai kehidupan manusia di dunia ini maupun kehidupan diakhirat.Manusia secara alami memiliki tanggungjawab moral mempertimbangan tentang sesuatu yang baik atau tidak baik.Pemahaman tentang keTuhanan adalah sesuatu yang ensisal dalam diri manusia, kemudian dirumuskan dalam sebuah ajaran.Inilah yang dilakukan oleh seorang teolog yang sangat berpengaruh pada abad ke-19 yaitu Friedrich Daniel Ernst Scheiermacher. Hermann J. Meyer

\footnotetext{
${ }^{6}$ Hermann J. Meyer, Perpustakaan Grofchen Meyer dari Claffiker Jerman untuk semua kelas, Biografi Friedrich Schleiermacher. Dicetak oleh Bibliographilchen Inftitut Bork Baru, hal 5-6.
}

mencatat tentang biografi Schleiermacher:

Friedrick Daniel ErnstLahir 21

November 1768 di Brelau (Polandia), Ayahnya Gottlieb Schleiermacher dan Ibu Katrina-Maria Schleiermacher. Ayah seorang pendeta dan ibunya seorang yang sangat saleh.

Pendidikan:Usia 15 tahun( 1783) sekolah di seminari Moravian di Nesky (aliran Pietisme).Usia 17 tahun(1785) ia pindah ke seminari teologi Moravian di Barby sesuai arahan orang ayahnya.Tahun 1787 melanjutkan studi ke universita Halle, mendalami pemikiran filsafat Immanuel Kant dan filsafat Yunani lainnya Usia 22 tahun 1790 melanjuti studi di universitas Berlin. Ia Melayani menjadi pendeta di Gereja Reformed (Kalvinis) di Prussia Barat. Tahun 1793 melayani di Barlin.Tahun1794 ditabiskan menjadi pendeta pada rumah sakit Charta di Berlin.Tahun 1802 menjadi pengkhotbah Pengadilan di Stolpe.Tahun 1806 kembali ke Berlin menjadi pembicara secara umum dan politik, mendapat gela profesor dan menjadi guru besar di Berlin. $^{6}$

Rut Jackson memberikan ulasan penting tentang Schleiermacher bahwa "ia menerbitkan tulisannya On Religion teks yang paling penting dan kontroversi dibidang filsafat agama, dan yang membangun reputasinya diseluruh dunia. Scheiermacher memegang jabatan professor pertamadi Halle dan kemudian di universitas Berlin yang baru didirikannya."

Schleiermacher memiliki pengaruh yang mengubah dibidang teologi, hermeneutik dan etika. Schleiermacher menjadi figur yang terkemuka dan menjadi

\footnotetext{
${ }^{7}$ Rut Jackson, An Analysis of Friedrich Scheiermacher on Religion, (Published by Macet International L.td, 2018 ) 15.
} 
Jurnal Teologi \& Pelayanan ( Kerusso )

E-ISSN: 2714-9587

P-ISSN: 2407-554X

orang kunci untuk nasionalisme Jerman selama pergolakan perang Napoleon. "Pemikiran Scheiermacher berdiri sebagai monument keteganggan antara rasionalisme pencerahan dan filsafat Romantisme Jerman, dan telah memiliki pengaruh yang luar biasa pada sejarah pemikiran protestan modern."

\section{Pandangan Tentang Agama}

Agama bukan hanya dipahami secera positif dari tokoh-tokoh sejarah, tetapi dari sisi negatifjuga, misalnya Feuerbach seorang humanis mengatakan bahwa "agama memalingkan manusia dari dirinya sendiri dan dari tugasnya di dunia ini, Friedrich Nietzche " agama praktis menyangkal arti hidup, merupakan institusi penyangkalan diri sendiri ... Sigmund Freud agama adalah tempat pelarian, khususnya pelarian ke kanakkanakan." Agama dianggap sesuatu yang tidak penting bahkan dianggap penghalang dari perkembangan ilmu pengetahuan.

Scheiermacher seorang yang berpikir kritis dan mendalam, " Interpretasi teks Friedrich Scheiermacher tahun 1799 tentang agama ada ilustrasi yang sangat baik dari proses berpikir kratif. Dalam rangkain lima pidatonya yang dibuat dengan terampil, Scheiermacher berusaha untuk menyakinkan kelompok pemikir yang skeptis tentang agama." ${ }^{10}$ Schleiermacher ingin memberikan jawaban kepada kelompok skeptisisme yang memandang segala sesuatu tidak pasti, bagi Scheiermacher agama itu memberikan sesuatu yang

\footnotetext{
${ }^{8}$ Ibid, 15.

${ }^{9}$ Tom Jacobs SJ, Paham Allah dalam Filsafat, Agama-agama dan Teologi, ( Yogyakarta, Kanisius, 2006). 29

${ }^{10}$ Rut Jackson, An Analysis of Friedrich Scheiermacher on Religion, (Published by Macet International L.td, 2018 ). Hal 9

${ }^{11}$ WA Hoffecker, "Schleiermacher, Friedrich Daniel Ernst," dalam Walter A Elwell, ed., Evangelical Oictionary of Theology (Grand Rapids Baker, 1984), hal. 982
}

penting dan pasti.

WA Hoffeker mengatakan

"Schleiermacher menekankan suatu agama etika, yang ia definisikan sebagai Felling of absolute dependency "perasaan

kebergantungan secara mutlak" atau "kesadaran akan Allah" ${ }^{11}$ Demikian juga yang dijelaskan oleh Paul T. Nimmo "Jika perasaan ketergantungan mutlak, yang mengungkapkan sebagai kesadaran diri akan Tuhan adalah tingkat tertinggi dan merupakan elemen esensial dari sifat manusia." 12 F.D. Wellem juga menjelaskan bahwa "Agama bukanlah terdiri dari sejumlah dogma atau sejumlah preposisi intelektual yang kepadanya orang-orang percaya menyatakan persetujuannya, tetapi agama muncul dari Gefuhl (pengalaman keagamaan=perasaan).

Andreas Arndt menjelaskan bahwa "dalam pidato edisi keduanya tahun 1806 Schleiermacher menentukan persepsi dan perasaan sebagai dua kemampuan potensi: Intuisi menyampaikan pengalaman totalitas yang subjektifnya berada di sisi perasaan." ${ }^{13}$ Lebih jauh Schleiermacher juga "mendefinisikan ulang agama sebagai sesuatu yang berakar pada intuisi atau perasaan.Ini adalah definisi yang akan menjadi sinyal penting bagi teologi modern." 14 Kesalehan tidak mungkin hanya naluri yang mendambakan fragmenframen metafisika dan etika yang berantakan.

Agama sejati adalah rasa dan selera untuk yang tak terhingga. ${ }^{15}$ Selanjutnya Toni menguraikan dalam bukunya bahwa Schleiermaceher membawa perbedaan

\footnotetext{
${ }^{12}$ Friedrich Schleiermacher, The Christian Faith, Pen. Paul T. Nimmo, University Of Aberdeen, April 2016),49

${ }^{13}$ Andreas Arndt, Friedrich Schleiermacher als Philosoph, Library of Congress Cataloging-in Publication data, A CIP Catalog record for is book has been applied for the Library of Congress. (Berlin/Boston,Druck: Hubert \& Co. GmbH Co. KG. Gottingen Priented Ing Germani), 22.

${ }^{14}$ Rut Jackson, An Analysis of Friedrich Scheiermacher on Religion, 9.

${ }^{15}$ Toni Lane, Runtut Pijar, hal. 198.
} 
yang jelas antara agama dan akal.Ia menekankan pengalaman, bukan iman, sebagai inti agama." ${ }^{16}$ Bagi Schleiermacher agama itu berdiri sendiri bukan masuk dalam ranah doktrin atau dogma serta berada diluar teologi.

Dari beberapa uraian diatas dapat dilihat secara komprehenship bahwa tujuan Scheiermacher mengenai hipotesa bahwa agama adalah perasaan kebergantungan yang absolut sebagai jawaban bagi orangorang yang berpikir skeptis tentang agama. Schleiermacher yakin bahwa perasaan kebergantungan sama pada semua agama yang pada akhirnya adalah membawa manusia memiliki hubungan harmonis dengan Tuhan.

\section{Pandangan Tentang Allah}

Allah adalah sang pencipta yang tak terbatas, pengenalan akan Allah akan mengubah hidup banyak orang. Allah adalah pribadi yang sempurna, Maha agung dan berdaulat atas seluruh ciptaanNya. Konsep tentang Allah dan keberadaanNya menimbulkan perseptif yang berbeda dari setiap tokoh teologi dari abad keabad, Georg W. F. Hegel mengatakan " hanya pikiran yang riil; setiap hal lain merupakan ekspresi dari pikiran... semua realitas (adalah) suatu ekspresi dari absolut, yang adalah Allah. Semua yang ada adalah ekspresi dari pikiran ilahi, sehingga apa yang riil adalah rasional dan apa yang rasional adalah rill." ${ }^{17}$ Immanuel Kant " konsep tentang Allah harus berasal dari penalaran; oleh karena itu, ia menyerang bukti-bukti tentang keberadaan Allah, dengan menyangkali keabsahannya." ${ }^{18}$ Konsep tentang Allah bertumpu pada pemikiran manusia yang absolut dan nyata bukan

\footnotetext{
${ }^{16}$ Ibid, 199.

${ }^{17}$ Paul Enns, The Moody Handbook of Theology, buku Pegangan Teologi, Penj. Rahmiati Tanudjaja. ( Malang: Literatur SAAT, 2012,) 192. ${ }^{18} \mathrm{Ibid}, 191$.

${ }^{19}$ Harun Hadiwijono, Teologi Reformatoris Abad ke-20 ( Jakarta: BPK. Gunung Mulia, 1993),16.
}

pada sesuatu yang abstrak dan adikodrati.

Pada saat meresponi situasi pandangan pencerahan dan Romantik maka Schleiermacher menggunakan metode introspeksi diri " segera aku mengarahkan pandanganku ke dalam, kepada diriku yang paling dalam, segeralah aku berada di dalam kawasan kekekalan."19 Selanjutnya mengatakan bahwa "jika boleh saya katakana secara kasar antara Tuhan yang berada diluar dan diatas dunia, dan Tuhan yang ada di dunia, tidak secara khusus memenuhi intinya, karena tidak ada yang dapat secara tegas dikatakan tentang Tuhan dalam hal antithesis internal dan eksternal tanpa membahayakan kemahakuasaan dan kemahahadiran Ilahi." 20

F.D Wellem dalam bukunya menjelaskan pandangan Scheiermacher tentang Allah bahwa " kita tidak mempunyai pengetahuan yang obyektif tentang Allah. Kita mengetahui Allah dalam hubungan dengan diri kita sendiri, dalam perasaan kebergantungan yang absolut kepada-Nya dan dalam hubungan dengan Allah dan alam semesta. ${ }^{21}$ Bagi Schleiermacher untuk mengenal Allah tidak tergantung pada rasio tetapi pada pengalaman (felling).

Schleiermacher selanjutnya menjelaskan bahwa manusia mampu memiliki kesadaran yang langsung mengenai Allah ... kesadaran diri ini sebagai suatu kesadaran ketergantungan mutlak yang ketika didalami diakui sebagai suatu kebergantungan kepada Allah. Kesadaran akan Allah (ada) dalam kesadaran diri dengan suatu cara yang sedemikian rupa sehingga keduanya tidak

\footnotetext{
${ }^{20}$ Friedrich Schleiermacher, The Crhristian Faith, Peny. H.R. Mackintosh dan J.S. Stewart, ( New York: T\&T Clark Ltd, 1999), 39

${ }^{21}$ F.D Wellem, Riwayat Hidus Singkat Tokohtokoh dalam sejarah Gereja, ( Jakarta: BPK Gunung Mulia, 2011), 168
} 
Jurnal Teologi \& Pelayanan ( Kerusso )

E-ISSN: 2714-9587

P-ISSN: 2407-554X

dapat dipisahkan." 22

Artinya Allah yang jauh diluar alam tak terhampiri, melampaui segala yang ada, Allah yang tak tebatas (transcendent) menjadi Allah yang dekat, bersekutu dengan makhluk ciptaan (immanent) hanya dapat dirasakan melalui hubungan perasaan dan kesadaran diri sendiri.

\section{Pandangan Tentang Kristus}

Konsep Schleiermacher tentang Allah sangat mempengaruhi pandangan tentang pribadi Kristus. Pengamatan Schleiermacher kepada Kristus juga dipengaruhi oleh pandangan terhadap dosa, yang menganggap bahwa dosa bukan sebagai suatu pelanggaran terhadap hukum Allah, dosa sebagai peristiwa dimana manusia berusaha untuk hidup sendiri, terpisah dari alam semesta dan sesamanya." 23 "For Christ himself is free from everything by which the rise of sin in the individual is conditioned by reasen of this freedom from the inheritance of sin, Christ's God-consciusness developed from earliest childhood as an undisturbed relationship to and knowledge of God. God's actual being was in him, the indwelling God- consciousness was the true being of God him. ${ }^{24}$

Yesus dipahami sebagai manusia yang berbeda dari yang lainnya. " Kristus dibedakan dari orang-orang lain karena potensinya yang konstan dari kesadaran Allah yang dimiliNya, yakni keberadaan Allah yang asli dan actual di dalam Dia.

\footnotetext{
${ }^{22}$ Linwood Urban, Sejarah Ringkas Pemikiran Kristen, Pen, Liem Sien Kie, ( Jakarta: BPK Gunung Mulia, 2012), 278. hal. 196.

${ }^{23}$ Paul Enns, The Moody Handbook Theology,

${ }^{24}$ Martin Reder, Schleiermacher Life and and Thought, (Philadelpia: Fortress Press, 1973), 134

${ }^{25}$ Linwood Urban, dikutip dari Schleiermacher “Christian Faith”Sejarah Ringkas Pemikiran Kristen,
}

Sedemikian kuat "kesadaran Allah di dalam diri-Nya" menentukan Yesus “ setiap saat, dan konsekuensinya keberdiaman yang sempurna dari Yang Mahatinggi ini (menjadi) keberadaanNya yang khusus dalam pribadiNya yang terdalam. "25

"Kristus adalah manusia biasa yang kebetulan dipilih Allah untuk tidak mewarisi dosa asal, sehingga sejak lahir dia berhasil mengembangkan kesadaran rohaninya, kesadaran batiniah yang merupakan satu-satunya sarana untuk mengenal dan bersekutu dengan Allah. Kesempurnaan Yesus Kristus oleh karena Allah berkenan hadir di dalam Dia. Oleh karena Yesus Kristus adalah manusia yang bersifat Ilahi." ${ }^{26}$ pemahaman

Schleiermacher tentang Kristus "tidak mewarisi dosa asal, sehingga sejak ia lahir ia berhasil mengembangkan "his spiritual consciousness"nya atau kesadaran batiniah yang merupakan satu-satunya sarana/means untuk mengenal dan bersekutu dengan Allah."27

\section{Pandangan Tentang Keselamatan}

Esensi pandangan Schleiemacher tentang agama, Allah dan Kristus berpengaruh besar kepada teologinya tentang keselamatan. Schleiemacher memandang bahwa manusia tidak mengalami kerusakan total karena dosa tetapi memiliki kesadaran untuk berkomunikasi dan membangun hubungan dengan Allah. Menurut Schleiermcaher bahwa dosa adalah " kebergantungan manusia pada dirinya sendiri, dan mencari kepuasaan bagi dirinya sendiri, bukan

Pen. Liem Sien Kie ( Jakarta: BPK Gunung Mulia, 2012). 279

${ }^{26}$ Made Christian Stanley Mawikere, Sola Experientia, Suatu analisis terhadap Teologi Schleiermacher.Evagelical Jurnal Teologi Injili dan Pembinaan Warga Gereja, Volume 3, No. 2.Juli 2019.Hal 233.

${ }^{27}$ Yakub Susabda, Seri Pengantar Teologi Modern 1 ( Malang: Lembaga Informed Injili Indonesia), 25 . 
kepada Allah."28 Dalam konsep keselamatan Schleiermacher mengatakan bahwa "keselamatan adalah anugerah, namun anugerah dalam bentuk gerakan atau dorongan dari hati ( Impulse),yang memungkinkan manusia untuk memanfaat anugerah umum pada dirinya yaitu “ kesadaran akan Allah" Keselamatan yang sejati adalah pengalaman hidup dengan kesadaran akan Allah seperti Kristus.

Keselamatan manusia bukan terjadi karena penebusan darah Kristus. Dan juga bukan karena Kristus melakukan hal-hal yang ajaib yang dampaknya terjadi pada kehidupan manusia, tetapi Yesus menjadi penebus melalui jalan:

a. Membagi (sharing) atau mengambil bagian dalam setiap kondisi kehidupan manusia (pengalamanNya bisa menjadi pengalaman kita).

b. Melibatkan ( assuming) manusia dengan kehidupan dalam "kesadaran akan Allah" yang sempurna mengajar manusia untuk mempraktekan bagaimana hidup dalam kesadaran rohani yang sempurna. ${ }^{29}$

\section{Tinjauan Kritis Terhadap Pandangan Schleiermacher}

Setelah memperlajari pandangan Schleiermacher seperti yang diuraikan dalam beberapa poin diatas, maka penulis akan memberikan tinjauan teologis kristis kepada beberapa pandangan tersebut.

\section{Pandangan tentang Agama}

Schleiermacher menekankan suatu agama etika, yang ia definisikan sebagai Felling of absolute dependency "perasaan

\footnotetext{
${ }^{28}$ F.D Welem, Riwayat Hidup tokoh-tokoh Gereja hal, 168.

${ }^{29}$ Yakob Subsabda, Teologi Modern, 27.

${ }^{30}$ Rut Jackson, An Analysis of Friedrich Schleiermacher, "On Religion" (New York: Macat Internatonal Ltd, 2018), 6.
}

kebergantungan secara mutlak" atau "kesadaran akan Allah" Esensi agama bukanlah berpikir atau bertindak tetapi intuisi dan perasaan, karena objek agama kepada Yang Tak Terbatas, prinsip tertingginya realitas bukanlah "hal" yang dapat direpresentasikan atau digenggam dalam pikiran." ${ }^{\text {,30 Thomas H. Grome }}$ menjelaskan bahwa " Agama sebagai pencarian manusia pada hal-hal transenden di mana hubungan seseorang dengan dasar keberadaan yang paling pokok ( ulmitimate ground of Being) dibawa kedalam kesadaran dan diekspresikan entah bagaimana caranya." ${ }^{31}$ Sedangkan menurut J.B. Job "agama "threskia" (Yunani) berarti ungkapan lahiriah dari kepercayaan, Kisah Para Rasul 26:5 “agama” berarti Yudaisme" Yakobus 1:26,27 diterjemahkan kata "ibadah" atau ibadah yang murni.",32

Dari sisi Teologis agama Kristen harus dilihat dari dua sisi yaitu lahirnya gereja ( KPR. 2) dan penyebutan nama Kristen untuk yang pertama kali di Antiokhia (KPR. 11:26). Kalau selidiki dari dua peristiwa ini, maka agama Kristen berbeda pengertiannya dari agama lain. Agama dari sisi teologis adalah Allah yang datang mencari manusia bukan manusia yang mencari Allah." Ketika mereka mendengar bunyi langkah TUHAN Allah, yang berjalan-jalan dalam taman itu pada waktu hari sejuk, bersembunyilah manusia dan istrinya itu terhadap TUHAN Allah diantara pohon-pohonan dalam taman. Tetapi Tuhan memanggil manusia itu dan berfirman kepadanya: " Di manakah engkau"( Kejadian 3:8-9).

Ketika manusia jatuh kedalam dosa, tabiat pertama yang muncul dalam diri manusia adalah rasa malu dan takut, sehingga manusia

\footnotetext{
${ }^{31}$ Thomas H. Grome, Christian Religius Education, Pendidikan Agama Kristen, Pen. Daniel Stefanus, (Jakarta: BPK Gunung Mulia, 2014), 32.

32 J.B. Job, Ensiklopedi Alkitab Masa Kini (AL) “ agama” Pen. Martin B. Daiton, Peny. Broto Semedi, ( Jakarta: Yayasan Komunikasi Bina Kasih/OMF, 1992), 15.
} 
Jurnal Teologi \& Pelayanan ( Kerusso )

E-ISSN: 2714-9587

P-ISSN: 2407-554X

bersembunyi dari hadapan Allah. Sehingga dalam perspektif teologis agama dipandang sebagai sesuatu yang dimulai dari atas ( dari Tuhan sendiri). Manusia beragama karena Tuhan yang menanam kesadaran ini.Tuhan memperkenalkan diri-Nya kepada manusia melalui perbagai Penyataan baik umum maupun khusus." 33

Kalau meruntut kepada kitab kejadian 3:8-9 dan Kisah Rasul 2 Hari Pentakosta lahinya Gereja serta panggilan Kristen kepada para pengikut Yesus dalam Kisah Para Rasul 11:26 maka agama Kristen berarti berjumpaan Allah yang suci dengan manusia yang berdosa, atas inisiatif Allah sendiri yang datang kedalam dunia berinkarnasi dalam pribadi Yesus Kristus dan atas karya Kristus itu sendiri agama Kristen ada sampai saat ini.

\section{Pandangan Tentang Allah}

Schleiermacher merasakan bahwa pemahaman gereja tentang Allah yang "transcendent" dan sekaligus juga "immanent" tidak mampu dijelaskan manusia pada zamannya.Akibatnya dalam hati manusia, ada suatu prasangka ada gap/jurang pemisah yang tak mungkin dapat dijembatani oleh manusia. ${ }^{34}$ Allah hanya bisa dirasakan melalui kesadaran diri dan perasaan kebergantungan mutlak.

Perlu dipahami bahwa Allah adalah pribadi yang agung transcendent tidak terjangkau oleh akal dan pikiran manusia." Kitab suci memperlihatkan dua fakta: Allah yang tak dapat dipahami; dan Allah yang dapat diketahui. Allah tak dapat dipahami menegaskan bahwa pikiran kita tidak mampu menguasai pengetahuan

\footnotetext{
${ }^{33}$ Hendi Rusli, Agama dalam Perspektif Teologi dan Sosiologi, Maret 2009.

${ }^{34}$ Yakub Susabda, Teologi Modern 1, 10.

${ }^{35}$ Chares C. Ryrie, Teologi Dasar 1, Panduan Populer untuk memahami keberan Alkitab ( Yogyakarta: Yayasan ANDI, 1992),33.
}

tentang Dia, Allah yang dapat diketahui, menyatakan bahwa Ia dapat dikenal, keduanya benar." 35

Selanjutnya Charles Ryrie mengatakan bahwa "Di dalam pengetahuan akan Allah, manusia hanya dapat memperolehnya sejauh Allah menyatakannya. Jika Allah tidak mengambil inisiatif untuk menyatakan diriNya, mustahil manusia dapat mengenalNya." ${ }^{36}$ kata Allah aslinya adalah nama jenis, atau kategori atau natur, eksistensi sama seperti manusia, bukan nama diri contoh "Henri" ada nama diri ... Allah memiliki nama diri yaitu YHWH"37

Keluaran 3:13-14 Lalu Musa berkata kepada Allah: "Tetapi apabila aku datang mendapatkan orang Isreal dan berkata kepada mereka: Allah nenek moyangmu telah mengutus aku kepadamu, dan mereka bertanya kepadaku: bagaimana tentang nama-Nya? apakah yang harus kujawab kepada mereka? Firman Allah kepada Musa: "AKU ADALAH AKU." Lagi Firman-Nya " Beginilah kaukatakan kepada orang Israel itu: AKULAH AKU telah mengutus aku kepadamu"

Allah berkenan dan berinisiatif menyatakan diri-Nya agar dikenal oleh ciptaanNya. "Ada dua cara Allah menyatakan diri-Nya, disebut penyataan umum dan penyataan khusus...penyataan umum melalui ciptaan, Manusia, sedangkan penyataan khusus adalah Alkitab." $" 38$

Untuk mengenal Allah dengan kesadaran diri atau perasaan tentu tidak mungkin karena manusia telah mati, Efesus 2: Kamu dahulu sudah mati karena pelanggaran-pelanggaran dan dosadosamu. Ef. 4:17b-18 Jangan hidup lagi

\footnotetext{
${ }^{36}$ Chares C. Ryrie, Teologi Dasar 1, Panduan Populer untuk memahami keberan Alkitab ( Yogyakarta: Yayasan ANDI, 1992), 35.

${ }^{37}$ Henri Veldhuis, Aku tahu yang ku percaya, sebuah Penjelasan tentang Iman Kristen, Penj. A.S. Hadiwiyata, Peny. Agustinus Setiawidi, ( Jakarta: Bpk. Gunung Mulia, 2010), 8.

${ }^{38}$ Charles C. Ryie, Teologi Dasar, 37.
} 
sama seperti orang-orang tidak mengenal Allah dengan pikirannya yang sia-sia dan pengertiannya yang gelap, jauh dari persekutuan dengan Allah, karena kebodohan yang ada di dalam mereka dan karena kedegilan hati mereka.

Kejatuhan manusia kedalam dosa membuat keseluruhan hidupnya, baik hati, pikiran dan kehendak tercemar oleh dosa, bahkan kecenderungan hati manusia membuahkan segala kejahatan (Kejadian 6:5).

\section{Pandangan Tentang Kristus}

Penilaian Schleiermacher tentang Yesus hanya sebagai manusia biasa yang "kebetulan" dipilih Allah untuk tidak mewarisi dosa asal, sehingga sejak lahir Yesus dapat mengembangkan his spiritual consciousness( kesadaran batiniahnya). Christ is originally human and like all men in virtue of this humanity; yet wholly superior to humantity in prossessing an unclouded awarenesss of God." 39

Mengganggap bahwa Yesus adalah manusia biasa tentu padangan yang keliru karena sesungguh Yesus adalah Allah yang menjadi manusia. Yohanes 1:1,14 "Pada mulanya adalah Firman; Firman itu bersama-sama dengan Allah dan Firman itu adalah Allah. Dalam teks aslinya $\varepsilon v \alpha \rho \chi \eta$

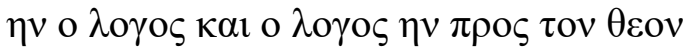

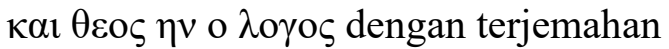
"Pada mulanya adalah Firman, Firman itu bersama-sama dengan Allah, dan Allah-lah Firman itu.Kata " $\square \square$ " menggunakan tense imperfek menunjukan keberadaan logos yang kontinyu. Kata Logos( $\square \square \square \square \square \square$ Firman dalam bahasa Yunani dalam bentuk perfekt tense, yang menyatakan bahwa keberadaan Logos sudah ada secara terus-

\footnotetext{
${ }^{39}$ Chleiemacher, Christian of Faith, 1963, 425.

${ }^{40}$ Pangeran Manurung, Menguji Kristologi Saksi Yehuwa, Kristologi Rasul Yohanes vs Saksi Yehuwa Menghadapi Ajaran Sumbang Lewat Injil Yohanes 1 ( Surbaya: Memra Publising, 2015), 105. ${ }^{41}$ Graig Evans, Word and Glory, On the Exegetical and Theological Background of John's Prologue ( Sheffield: JSOT, 1993), 79.
}

menerus di masa lalu. ${ }^{40} \quad$ Craig Evans menyimpulkan secara bahasa kata "mulanya" dalam kejadian 1 dan Yohanes 1 memperlihatkan arti sebuah kekekalan, yaitu sebelum ada segala ciptaan. Kekekalan disini diakui oleh para Sarjana Alkitab sebagai salah satu alasan terhadap pengakuan keilahian Logos ( Yesus Kristus) karena Dia kekal adanya. ${ } 41$ Kata sandang" $\square \square \square \square$ "(pros) tidak sekedar dipahami sebagai posisi tetapi di mengerti sebagai "Logos berada dalam persekutuan yang aktif dengan Allah” karena digunakan bagi pribadi Allah, kata pros tersebut menunjukan persekutuan internal yang kekal dalam diri Allah." ${ }^{42}$

Yohanes 1:14 " Firman itu telah menjadi manusia, dan diam diantara kita, dan kita telah melihat kemuliaan-Nya, yaitu kemuliaan yang diberikan kepadaNya sebagai Anak tunggal Bapa, penuh kasih karunia dan kebenaran." Kalimat kunci “ kai ho Logos sarx egeneto" ( Firman menjadi daging),yang segera dilanjutkan dengan kata "kemah (skene) dan Kemuliaan (Doxa) Yesus. M. Pamment menjelaskan bahwa doxa (kemuliaan) adalah (1). kualitas yang ditinggikan, dihormati, dan terkenal atau (2).

Keagungan, Keindahan, atau kebesaran kegemilangan terang Surgawi." ${ }^{43}$ Kanagaraj menegaskan hal ini bahwa doxa dari Logos yang berinkarnasi adalah doxa dari Bapa. Karena kemuliaan itu diberikan oleh Bapa kepada Anak tunggalNya (monogenes) dank arena itu sama ensensinya. Kata monogenes berarti satu-satunya, atau unik."44

Secara eksistensi Yesus adalah Allah sang Pencipta " Segala sesuatu dijadikan oleh Dia dan tanpa Dia tidak ada

\footnotetext{
${ }^{42}$ Pangeran Manurung, Menguji Kristologi Saksi Yehuwa, 106

${ }^{43}$ M. Pamment, "The Meaning of Doxa in the Fourth Gospel” ZNW 74, 1983, 12.

${ }^{44}$ Mangapul Sagala," menguti Jay J. Kanagaraj (1998), Kemuliaan Yesus Menyingkap Kristologi Injil Yohanes, ( Jakarta: Literatur Perkantas, 2015), 61.
} 
suatu pun yang telah jadi dari segala yang telah dijadikan ( Yohanes 1:3). "kata logos di dalam ayat 3 digantikan kata autou adalah penyebab segala ciptaan yang ada. Sebaliknya tanpa outou (logos), maka tidak akan ada ciptaan dan tidak akan pernah ada "segala sesuatu". ${ }^{45}$

Yesus adalah pribadi yang kekal “ Aku adalah Alfa dan Omega, firman Tuhan Allah, yang ada dan yang sudah ada dan yang akan datang Yang Mahakuasa. (Wahyu 1:8). Yesus dan Bapa adalah satu “ Aku dan Bapa adalah Satu" (Yohanes 10:30) masih banyak ayat-ayat lain yang membuktikan bahwa Yesus adalah Allah sejati dan juga Yesus juga manusia sejati. Hal ini diteguhkan kembali dalam konsili Chalcedon (th. 451) yang menggariskan hubungan antara dua nature (divinity and humanity) Kristus. Bahwa Kristus betulbetul Allah sejati dan manusa sejati.Dua natur ini "without confusion, whithout change, whithout division, without separation/tidak bercampur, tidak berberubah, tidak terpisah, tidak terbagibagi." 46

\section{Pandangan Tentang Keselamatan}

Keselamatan dalam Kristus terjadi bukan oleh karena Kristus melakukan halhal yang ajaib yang dampaknya terjadi dalam hidup manusia... Ia menyebutkan bahwa peranan Kristus adalah “ educative influence as a continuation of the divine".Inti dari penekanan Schleiermacher tentang keselamatan adalah "personal experience ( Pengalaman pribadi)"47 Bagi penulis pengalaman pribadi dalam hal spiritual itu penting tetapi bukan esensi dari keselamatan, pengalaman itu hanya hasil keselamatan yang telah dikerjakan Yesus

\footnotetext{
${ }^{45}$ Pangeran Manurung, 115.

${ }^{46}$ Yakub B. Susabda, hal 20-21.

${ }^{47}$ Yakub B. Susabda, dikutip dari (Christian Faith 1963, 425), hal 26.

${ }^{48}$ Chris Marantika, mengutif (J.H. Thayer, A. Greek-English Lexicon of The New Testament, New
}

Kristus sehingga orang percaya memiliki relationship dengan Allah. Esensi keselamatan terdapat pada " anugerah Allah" Efesus 2:8-9 "Sebab karena kasih karunia kamu diselamatkan oleh iman; itu bukan hasil usahamu, tetapi pemberian Allah, itu bukan hasil pekerjaanmu: jangan ada orang yang memegahkan diri." Yesus adalah pokok dan pemberi dari kasih karunia itu, "Sebab hukum Taurat diberikan oleh Musa, tetapi kasih karunia dan kebenaran datang oleh Yesus Kristus' ( Yohanes 1:17).

Menurut Thayer kasih karunia merupakan perbuatan Allah yang berhubungan dengan hal-hal rohani, di mana Tuhan menurunkan pengaruh kesucian-Nya kepada jiwa manusia dan mengijinkan mereka percaya kepada Kristus.Tuhan juga memelihara, menguatkan, menumbuhkan iman mereka, oleh karena pengetahuan dan kasih, serta menggalakan mereka untuk berlatih menghasilkan buah Kristen." 48

Kekejaman dan pengaruh kuasa dosa yang serius membuat semua usaha manusia dalam memperoleh keselamatan menjadi sia-sia.Chris Marantika menjelaskan bahwa akibat dosa sangatlah dalam dan fatal.Hal tersebut terjadi karena dilaksanakan terhadap Allah.Seriusnya dosa ialah karena bertentangan dengan pribadi dan karakter." 49 Karkater Allah yang dimaksud adalah" Karena itu haruslah kamu sempurna, sama seperti Bapamu yang di surga adalah sempurna. ( Matius 5:48) kata yang miring dan digaris bawahi dibuat penulis sebagai bentuk penekanan akan standar keselamatan itu. Maka berdasar standar itu tidak seorangpun yang layak dan mampu untuk mendapat

York: America Book Co, 1889, 666) Doktrin Keselamatan dan Kehidupan Rohani (Yogyakarta: Iman Press, Maret 2002), 36.

${ }^{49}$ Chris Marantika, Doktrin Keselamatan, hal. 
keselamatan.

Yakub B. Susabda

menjelaskan bahwa Alkitab menyaksikan bahwa keselamatan total yang terjadi oleh karena manusia percaya atas "segala sesuatu yang Allah telah lakukan melalui dan di dalam Kristus, termasuk Inkranasi, kematianNya, kebangkitanNya dan seterusnya. Oleh karena iman itu sendiri adalah anugerah, maka keselamatan itu dengan sendirinya adalah anugerah sematamata." 50

Jadi keselamatan adalah anugerah Allah semata-mata, dikerjakan oleh Yesus sendiri dengan cara mengorbankan diriNya, mati dikayu salib, dikuburkan dan bangkit pada hari yang ketiga lalu naik ke surga. Inilah pokok iman Kristen tentang keselamatan.

\section{Kesimpulan}

Setiap pemikiran teologi maupun filsafat yang berpengaruh pasti memiliki latar belakang mengapa pandangan itu muncul dan siapa tokohnya.Pada karya tulis ini pokok yang bahas adalah pandangan Friedrich Schleiermacher tentang Agama, Allah, Kristus dan keselamatan.Pokok-pokok ini menjadi hal menarik untuk dianalisis secara serius karena menyangkut doktrin dasar Kristen. Ada beberapa kesimpulan yang penulis dapat sajikan dalam bab ini yaitu:

Pertama, agama dalam konteks iman Kristen harus dipahami sebagai hasil perjumpaan Allah yang suci dengan manusia yang berdosa, sehingga terjadinya rekonsiliasi melalui karya Kristus. Agama tanpa inisiatif Allah untuk memperkenal diri adalah agama khayalan tanpa kepastian dan berpusat pada manusia (antroposentris).

Kedua, Allah adalah pribadi yang agung, transcendent tidak bisa dijangkau oleh manusia melalui cara apapun. Potensi yang baik dalam diri dan bantiah manusia yang disebut "feeling of absolute dependency" diyakini oleh Schleiermacher cara untuk mengalami dan berjumpa dengan Allah. Pandangan ini meniadakan kedaulatan Allah dalam kekudusan karakterNya dan sekaligus meniadakan seluruh inkarnasi Kristus serta karya-Nya dikayu salib.Dosa tidak dipandang sebagai sesuatu yang mutlak dan serius merusak hubungan manusia dengan Allah karena Schleiermacher masih meyakini potensi baik dalam diri manusia untuk berjumpa dengan Allah.

Ketiga, Kristus adalah Allah sejati yang menyatakan dalam diri dalam wujud insani menjadi manusia sejati dengan tujuan menyelamatkan manusia dari hukum dosa, melalui kematian, kebangkitan dan kenaikan-Nya ke surga.Yesus berdasarkan Alkitab sangat berbeda dengan pemahaman Schleiermacher yang hanya sebatas manusia ideal, berbeda dari manusia umumnya, yang secara senga dipilih Allah untuk tidak mewarisi dosa asal.Pandangan ini meniadakan nature Allah dalam Kristus dan mengabaikan seluruh karya Kristus yaitu kematian dan kebangkitan dalam keselamatan manusia.

Keempat, Keselamatan manusia dari dosa adalah karya Allah suatu inisiatif dari diri-Nya sendiri dan melalui karyaNya sendiri. Hal ini terjadi karena perbuatan dosa manusia mengakibatkan kerusakan total hubungan manusia dengan Allah. Usaha manusia untuk memulihkan hubungan dengan Allah melalui agama, ritual dan amal perbuatan baik adalah siasia, karena Allah memiliki standar mutlak sesuai dengan karakter-Nya yaitu kudus dan sempurna. Tuntutan Allah yang mutlak hanya dapat dicapai oleh diri-Nya melalui kehadiran Yesus kedalam dunia untuk mati dikayu salib, pengorbanan Kristus inilah yang membuat manusia dilayakan dan dibenarkan dihadapan Allah.

${ }^{50}$ Yakub B. Subsabda, Teologi Modern, hal 29 


\section{Pustaka}

[1] Alkitab. Jakarta: Lembaga Alktab Indonesia, 2001.

[2] Arndt, Andreas.Friedrich Schleiermacher als Philosoph, Library of Congress Catalogingin Publication data, A CIP Catalog record for is book has been applied for the Library of Congress. Berlin/Boston,Druck: Hubert \& Co. GmbH Co. KG. Gottingen Priented Ing Germani.

[3] B. Susabda,Yakub. Seri Pengantar Teologi Modern 1. Malang: Lembaga Informed Injili Indonesia.

[4] Brown, Colin. Philosophy and the Christian Faith.Chicago: IVP, 1969.

[5] Chia PS, Juanda J. Understanding The Relationship Between Faith and Knowledge. Journal DIDASKALIA. 2020 Apr 8;3(1):1-6.

[6] C. Ryrie, Chales. Teologi Dasar 1, Panduan Populer untuk memahami keberan Alkitab. Yogyakarta: Yayasan ANDI, 1992.

[7] Enns, Paul.The Moody Handbook Of Theology,Pen, Rahmiati Tanudjaja. Malang:SAAT, 2012.

[8] Evans, Graig. Word and Glory, On the Exegetical and Theological Background of John's Prologue. Sheffield: JSOT, 1993.

[9] H. Grome, Thomas.Christian Religius Education, Pendidikan Agama Kristen, Pen. Daniel Stefanus. Jakarta: BPK Gunung Mulia, 2014.
[10] Hadiwijono, Harun.Teologi Reformatoris Abad ke-20. Jakarta: BPK. Gunung Mulia, 1993.

[11] Hoffecker,WA. "Schleiermacher, Friedrich Daniel Ernst," dalam Walter A Elwell, ed., Evangelical Oictionary of Theology. Grand Rapids Baker, 1984.

[12] J. Meyer, Hermann. Perpustakaan Grofchen Meyer dari Claffiker Jerman untuk semua kelas, Biografi Friedrich Schleiermacher. Dicetak oleh Bibliographilchen Inftitut Bork Baru,

[13] Jackson, Rut. An Analysis of Friedrich Scheiermacher on Religion. Published by Macet International L.td, 2018.

[14] Jacobs SJ,Tom.Paham Allah dalam Filsafat, Agama-agama dan Teologi. Yogyakarta, Kanisius, 2006.

[15] Job, J.B. Ensiklopedi Alkitab Masa Kini (A-L) “agama” Pen. Martin B. Daiton, Peny. Semedi, Broto. Jakarta: Yayasan Komunikasi Bina Kasih/OMF, 1992.

[16] Kant, Immanuel. "Beantwortung der Frage: Was ist Aufklarung”. Berlinische Monatsshrift, December 1787 ( Gesammelte Schriften, Berlin, VIII).

[17] Lane, Tony. Runtut Pijar, Sejarah Pemikiran Kristiani, Pen, Conny item-Corputy Jakarta: BPK Gunung Mulia, 2015.

[18] Mackintosh, H.R. dan J.S. Stewart, Peny.The Crhristian Faith,(Friedrich Schleiermacher). New York: T\&T Clark Ltd, 1999. 
[19] Manurung, Pangeran. Menguji Kristologi Saksi Yehuwa, Kristologi Rasul Yohanes vs Saksi Yehuwa Menghadapi Ajaran Sumbang Lewat Injil Yohanes 1 Surbaya: Memra Publising, 2015.

[20] Marantika, Chris.mengutip (J.H. Thayer, A. Greek-English Lexicon of The New Testament, New York: America Book Co, 1889, 666) Doktrin Keselamatan dan Kehidupan

Rohani.Yogyakarta: Iman Press, Maret 2002.

[21] Pamment, M. "The Meaning of Doxa in the Fourth Gospel" ZNW 74, 1983.

[22] Paul T. Nimmo,Penj.The Christian Faith(Friedrich Schleiermacher). University Of Aberdeen, April 2016.

[23] Rusli, Hendi. Agama dalam Perspektif Teologi dan Sosiologi, Maret 2009.

[24] Sagala, Mangapul mengutip Jay J. Kanagaraj (1998), Kemuliaan Yesus Menyingkap Kristologi Injil Yohanes, Jakarta: Literatur Perkantas, 2015).

[25] Stanley Mawikere, Made. Christian Sola Experientia, Suatu analisis terhadap Teologi Schleiermacher. Evagelical Jurnal Teologi Injili dan Pembinaan Warga Gereja, Volume 3, No. 2.Juli 2019.

[26] Urban, Linwood. Sejarah Ringkas Pemikiran Kristen, Pen, Liem

Sien Kie. Jakarta: BPK Gunung Mulia, 2012.

[27] Veldhuis, Henri. Aku tahu yang ku percaya, sebuah Penjelasan tentang Iman Kristen, Penj. A.S. Hadiwiyata, Peny. Agustinus
Setiawidi, Jakarta: Bpk. Gunung Mulia, 2010.

[28] Wasugai, Amiruddin. Diskusi kelas persentasi kelompok 5 " Filsafat Eksistensialisme” mata kuliah Coloqium Didacticum, Sabtu, 10 Oktober 2020.

[29] Wellem, F.D. Riwayat Hidus Singkat Tokoh-tokoh dalam sejarah Gereja,Jakarta: BPK Gunung Mulia, 2011. 